\title{
ANALISIS PENGARUH KUALITAS SISTEM, PERSEPSI \\ KEMUDAHAN, IKLAN, PROMOSI, DAN HARGA \\ TERHADAP KEPUASAN PENGGUNA \\ APLIKASI RUANGGURU
}

\author{
Kezia Stefani ${ }^{1}$ \\ Henry Cilvanus
}

$\underline{\text { kezia@likmi.ac.id }}^{\mathbf{1}}$

\begin{abstract}
ABSTRAK
Ruangguru merupakan perusahaan penyedia layanan dan konten pendidikan yang berbasis teknologi. Penelitian ini akan menganalisis faktor-faktor yang mempengaruhi kepuasan pengguna aplikasi RuangGuru.

Hasil uji hipotesis berdasarkan uji t atau uji parsial menunjukkan bahwa kualitas sistem, persepsi kemudahan, iklan,promosi, dan harga berpengaruh secara signifikan terhadap kepuasan pengguna. Hasil uji hipotesis berdasarkan uji f atau uji simultan menunjukkan bahwa kualitas sistem, persepsi kemudahan, iklan, promosi, dan harga berpengaruh secara bersama-sama terhadap kepuasan pengguna.

Koefisien determinasi menunjukkan pengaruh kualitas sistem, persepsi kemudahan, iklan, promosi, dan harga secara bersama-sama terhadap kepuasan pengguna sebesar $62,3 \%$ dan sisanya sebesar $37,7 \%$ dipengaruhi oleh faktorfaktor lain yang tidak dibahas dalam penelitian ini.
\end{abstract}

Kata kunci : Kualitas Sistem, Persepsi Kemudahan, Iklan, Promosi, Harga, Kepuasan Pengguna, Aplikasi Ruangguru

\section{PENDAHULUAN}

Ruangguru merupakan perusahaan teknologi terbesar dan terlengkap di Indonesia yang berfokus pada layanan berbasis pendidikan dan telah memiliki lebih dari 6 juta pengguna serta telah mengelola lebih dari 150.000 guru yang menawarkan jasa di lebih dari 100 bidang pelajaran. Perusahaan ini didirikan sejak tahun 2014 oleh Belva Devara dan Iman Usman, yang keduanya berhasil masuk dalam jajaran pengusaha sukses dibawah 30 tahun melalui Forbes 30 under 30 untuk teknologi konsumen di Asia. Pada Februari 2016, Ruangguru memperkenalkan versi beta-nya dari aplikasi Android dan versi penuh pada bulan April. Pada 5 Juli 2017, UOB Venture Management dikabarkan mendanai Ruangguru sebagai pendana ketiga.

Ruangguru berkomitmen untuk menjadi mitra bagi pemerintah daerah demi memberikan pendidikan berkualitas melalui Sistem Manajemen Belajar (LMS). Tahun lalu, Ruangguru berhasil bekerja sama dengan 32 (dari 34) pemerintah provinsi dan lebih dari 326 pemerintah kota dan kabupaten di Indonesia. Selain itu, Ruangguru juga menawarkan video belajar berlangganan, marketplace les privat, layanan bimbingan belajar on-demand, tryout ujian online, dan lain-lain. 
Penelitian ini akan menganalisis pengaruh kualitas sistem, persepsi kemudahan, iklan, promosi, dan harga terhadap kepuasan pengguna aplikasi Ruang Guru. Berdasarkan uraian di atas, rumusan masalah yang digunakan adalah :

a. Bagaimana pengaruh kualitas sistem terhadap kepuasan pengguna aplikasi Ruangguru?

b. Bagaimana pengaruh persepsi kemudahan terhadap kepuasan pengguna aplikasi Ruangguru?

c. Bagaimana pengaruh iklan terhadap kepuasan pengguna aplikasi Ruangguru?

d. Bagaimana pengaruh promosi terhadap kepuasan pengguna aplikasi Ruangguru?

e. Bagaimana pengaruh harga terhadap kepuasan pengguna aplikasi Ruangguru?

f. Bagaimana pengaruh kualitas sistem, persepsi kemudahan, iklan, promosi dan harga secara bersama-sama terhadap kepuasan pengguna aplikasi Ruangguru?

\section{LANDASAN TEORI}

\subsection{Sistem Informasi}

"Sistem informasi adalah sekumpulan komponen yang saling berhubungan, mengumpulkan, memproses, menyimpan, dan mendistribusikan informasi untuk menunjang pengambilan keputusan dan pengawasan dalam suatu organisasi." (Loudon and Loudon, 2014:15)

Jeperson Hutahaean (2014:13) mengartikan pengertian dari sistem informasi sebagai berikut: Sistem informasi adalah suatu sistem didalam suatu organisasi yang mempertemukan kebutuhan pengelolaan transaksi harian, mendukung operasi, bersifat manajerial, dan kegiatan strategi dari suatu organisasi dan menyediakan pihak luar tertentu dengan laporan laporan yang dibutuhkan.

\subsection{Definisi dan Konsep Variabel Penelitian}

\subsubsection{Kualitas Sistem}

"Kualitas sistem digunakan untuk mengukur kualitas sistem teknologi itu sendiri". Jogiyanto (2007:12)

"Kualitas sistem merupakan suatu ukuran pengolahan sistem informasi itu sendiri". Chen (2010:310)

Menurut Nelson (2005:206) menjelaskan kualitas sistem dapat diukur melalui lima indikator antara lain:

a. Reliabilitas sistem, mengukur keandalan atas sistem yang dioperasikan.

b. Fleksibilitas sistem, sistem dapat menyesuaikan dengan berbagai kebutuhan pengguna dan ke kondisi yang berubah-ubah.

c. Integrasi sistem, sistem memudahkan dalam menggabungkan data dari berbagai macam sumber untuk mendukung pengambilan keputusan bisnis.

d. Aksesibilitas sistem, kemudahan untuk mengakses informasi ataupun kemudahan untuk menghasilkan informasi dari suatu sistem.

e. Waktu respon sistem, mengasumsikan respon sistem yang cepat atau tepat waktu terhadap permintaan akan informasi.

\subsubsection{Persepsi Kemudahan}

Menurut Davis (1989) mendefinisikan percieved ease of use sebagai keyakinan akan kemudahan penggunaan, yaitu tingkat kepercayaan user bahwa teknologi atau sistem tersebut dapat digunakan dengan mudah dan bebas dari masalah. Intensitas penggunaan dan interaksi antara pengguna dengan sistem juga dapat menunjukkan kemudahan penggunaan. Davis (1989) memberikan beberapa 
indikator percieved ease of use: ease of learn, controllable, clear and understandable, flexible, ease to become skillful, ease to use.

Berikut ini merupakan penjelasan dari masing-masing indikator persepsi kemudahan penggunaan (perceived ease of use) menurut Davis (1989) dan Noviarni (2014):

a. Mudah dipelajari/dipahami (ease of learn) artinya konsumen dapat dengan jelas memahami bagaimana mempelajari sistem transaksi melalu web ritel.

b. Dapat dikontrol (controllable) artinya fasilitas dan fitur yang disediakan dalam website berfungsi dengan baik.

c. Jelas dan dapat dipahami (clear and understandable) maksudnya fasilitas atau fitur website sesuai dengan kegunaanya, fitur yang disajikan lengkap dan tidak menimbulkan persepsi lain.

d. Fleksibilitas (flexible) adalah transaksi dapat dilakukan dengan tampa hambatan dan dapat dilakukan kapan saja tanpa terbatas oleh tempat dan waktu.

e. Mudah untuk menjadi terampil/mahir (easy to become skillful) maksudnya dalam penggunaan selanjutnya konsumen dapat mengakses website dengan mudah sesuai keinginanya setelah satu kali menggunakan.

f. Mudah dioperasikan/digunakan (easy to use) maskudnya melalui retail web proses transaksi dapat dilakukan dengan mudah dan dinamis, tidak menimbulkan kesulitan dalam proses pembelian maupun penyewaan barang.

\subsubsection{Iklan} berikut:

Menurut para ahli, iklan mempunyai definisi yang beragam, yaitu sebagai

"Segala bentuk penyajian non personal dan promosi ide, barang dan jasa dari suatu sponsor tertentu yang memerlukan pembayaran. "(Kotler, 1997)

"Pesan dari produk, jasa atau ide yang disampaikan kepada masyarakat melalui suatu media yang di arahkan untuk menarik konsumen. ”(Rhenald Kasali, 2000)

Berdasarkan pengertian tersebut dapat disimpulkan bahwa iklan adalah suatu presentasi dan promosi gagasan melalui suatu media untuk menarik komsumen. Menurut Kotler (2013:143) indikator iklan adalah sebagai berikut:

Mission (tujuan) yaitu menetapkan tujuan periklanan yang merujuk pada keputusan sebelumnya mengenai pasar sasaran, penentuan pasar sasaran, penentuan posisi pasar, dan bauran promosi. Strategi penentuan posisi pemasaran dan strategi bauran pemasaran mengidentifikasikan tugas yang harus dilaksanakan periklanan dalam pelaksanaan program pemasaran keseluruhan.

a. Message (pesan yang disampaikan), idealnya suatu pesan harus mendapat perhatian, menarik, membangkitkan keinginan, dan menghasilkan tindakan.

b. Media (media yang digunakan), pada dasarnya pemilihan media adalah mencari cara dengan biaya yang paling efektif untuk menyampaikan sejumlah pemberitahuan yang dikehendaki kepada pasar sasaran. Pengaruh pemberitahuan iklan terhadap kesadaran khalayak sasaran tergantung kepada jangkauan, frekuensi dan dampak iklan.

\subsubsection{Promosi}

Menurut para ahli, promosi memiliki definisi yang beragam sebagai berikut :

"Arus informasi atau persuasi satu-arah yang dibuat untuk mengarahkan seseorang atau organisasi kepada tindakan yang menciptakan pertukaran dalam pemasaran." (Swastha, 2007:237) 
"Promosi merupakan suatu ungkapan dalam arti luas tentang kegiatan-kegiatan yang secara efektif dilakukan oleh perusahaan (penjual) untuk mendorong konsumen membeli produk atau jasa yang ditawarkan." (Sukirno, 2014:194)

Semua usaha dalam kegiatan promosi dilakukan melalui komunikasi yang menggunakan kombinasi peralatan promosi yang disebut dengan bauran promosi. Menurut Kotler dan Amstrong (2008), menyatakan bahwa bauran promosi terdiri dari:

a. Advertising (Periklanan) yaitu setiap bentuk persentasi dan promosi nonpersonal yang memerlukan biaya tentang gagasan, barang, atau jasa oleh sponsor.

b. Sales Promotion (Promosi Penjualan) yaitu insentif-insentif jangka pendek untuk mendorong pembelian atau penjualan sebuah produk atau jasa.

c. Public Relation and Publicity (Hubungan Masyarakat dan Publisitas) yaitu membangun hubungan baik dengan berbagai publik perusahaan dengan sejumlah cara supaya memperoleh publisitas yang menguntungkan, membangun citra perusahaan yang bagus, dan menangani atau meluruskan rumor, cerita, serta event yang tidak menguntungkan.

d. Personal Selling (Penjualan secara Pribadi) yaitu persentasi personal oleh tenaga penjualan sebuah perusahaan dengan tujuan menghasilkan transaksi penjualan dan membangun hubungan dengan pelanggan.

e. Direct Marketing (Pemasaran Langsung) yaitu hubungan-hubungan langsung dengan masing-masing pelanggan yang dibidik secara seksama dengan tujuan baik untuk memperoleh tanggapan segera, maupun untuk membina hubungan dengan pelanggan yang langgeng.

\subsubsection{Harga}

Menurut para ahli, harga memiliki definisi yang beragam sebagai berikut :

"Harga adalah jumlah uang yang dibutuhkan untuk mendapatkan sejumlah kombinasi dari barang beserta pelayanannya." (Swastha, 2007:147)

"Harga adalah sejumlah uang sebagai alat tukar untuk memperoleh produk atau jasa atau dapat juga dikatakan penentuan nilai suatu produk dibenak konsumen." (Saladin, 2007:95)

Berdasarkan definisi para ahli diatas dapat disimpulkan bahwa harga merupakan sejumlah uang yang digunakan sebagai alat tukar agar dapat menentukan nilai suatu produk atau layanan. Indikator harga menurut (Tjiptono, 2008), yaitu:

a. Perbandingan harga dengan produk lain, yaitu bagaimana perbandingan harga produk dengan produk pesaingnya.

b. Kesesuaian harga dengan kualitas produk, yaitu apakah harga yang di tawarkan sudah sesuai dengan kualitas produk yang didapatkan.

c. Keterjangkauan harga, yaitu adalah keterjangkauan harga yang ditawarkan produsen kepada konsumen.

\subsubsection{Kepuasan Pengguna}

Tujuan utama dari suatu bisnis yaitu konsumen (pengguna) mendapatkan kepuasan dari sebuah produk bisnis yang dibuat oleh perusahaan. Kepuasan tersebut dapat memberikan dampak yaitu keharmonisan antara pelanggan dan konsumen (pengguna), kecenderungan untuk pembelian atau menggunakan kembali. Dalam subbab kepuasan pengguna, peneliti menguraikan beberapa definisi kepuasan pengguna menurut ahli. 
"Kepuasan konsumen adalah tingkat perasaan seseorang setelah membandingkan dengan harapannya." (Tjiptono, 2008: 353).

"Kepuasan pengguna adalah respon pemakai terhadap penggunaan keluaran sistem informasi." (Jogiyanto, 2007:23)

Menurut Somers et al. (2003:597) mengungkapkan bahwa ada lima dimensi pengukuran kepuasan pengguna, antara lain:
a. Content (Isi)
b. Accuracy (Akurasi)
c. Format (Format)
d. Timeliness (Ketepatan waktu)
e. Ease of use (Mudah digunakan)

\subsection{Keterkaitan Antar Variabel}

\subsubsection{Kualitas Sistem terhadap Kepuasan Pengguna}

Hasil dari penelitian yang dilakukan oleh Dian Septiayu Fendini, Kertahadi, dan Riyadi (2013) berjudul "Pengaruh Kualitas Sistem Dan Kualitas Informasi Terhadap Kepuasan Pengguna (Survei Pada Karyawan Pengguna Aplikasi Pelayanan Pelanggan Terpusat (AP2T) di PT. PLN (Persero) Area Malang)." Berdasarkan hasil pengujian menunjukkan hasil perhitungan secara parsial yaitu signifikansi $0,005<0,05$ yang berarti bahwa Kualitas Sistem (X2) berpengaruh signifikan terhadap kepuasan pengguna AP2T (Y).

$\mathrm{H}_{1}$ : Kualitas Sistem berpengaruh terhadap kepuasan pengguna aplikasi Ruangguru.

\subsubsection{Persepsi Kemudahan terhadap Kepuasan Pengguna}

Hasil dari penelitian yang dilakukan oleh Ni Made Sri Rukmiyati dan I Ketut Budiartha (2016) berjudul "Pengaruh Kualitas Sistem Informasi, Kualitas Informasi, dan Perceived Usefulness Pada Kepuasan Pengguna Akhir Software Akuntansi (Studi Empiris Pada Hotel Berbintang Di Provinsi Bali)." Berdasarkan hasil pengujian menunjukan hasil perhitungan secara parsial yaitu signifikansi 0.011 $<0.05$, yang berarti bahwa Perceived Usefulness (X3) berpengaruh signifikan terhadap kepuasan pengguna akhir software akuntansi (Y).

$\mathrm{H}_{2}$ : Persepsi Kemudahan berpengaruh terhadap kepuasaan pengguna aplikasi Ruangguru.

\subsubsection{Iklan terhadap Kepuasan Pengguna}

Hasil dari penelitian yang dilakukan oleh Nila Kasuma Dewi,SE, Gus Andri,SE.,MM, Sepris Yonaldi,SE.,MM (2012) berjudul "Pengaruh Iklan, Citra Merek, Dan Kepuasan Konsumen Terhadap Loyalitas Konsumen Dalam Menggunakan Vaseline Hand And Body Lotion Di Kota Padang ( Studi Kasus Di Pt. Unilever Cabang Padang ).'Iklan (X1) berpengaruh sebesar 0,425 terhadap loyalitas konsumen produk Vaseline Hand and Body lotion di kota padang (Y). $\mathrm{H}_{3}$ : Iklan berpengaruh terhadap kepuasan pengguna aplikasi Ruangguru.

\subsubsection{Promosi terhadap Kepuasan Pengguna}

Hasil dari penelitian yang dilakukan oleh Ronal Apriyanto (2016) berjudul "Pengaruh Promosi dan Pelayanan Terhadap Kepuasan Pelanggan Pada Toko BNJ Elektronik." Berdasarkan hasil pengujian menunjukan hasil perhitungan secara parsial yaitu signifikansi $0.000<0.05$, yang berarti bahwa promosi $(\mathrm{X} 1)$ berpengaruh signifikan terhadap kepuasan komsumen (Y).

$\mathrm{H}_{4}$ : Promosi berpengaruh terhadap kepuasan pengguna aplikasi Ruang Guru. 


\subsubsection{Harga terhadap Kepuasan Pengguna}

Menurut hasil dari penelitian yang dilakukan oleh Rendy Gulla, Sem George Oroh, Ferdy Roring (2015) berjudul "Analisis Harga, Promosi, Dan Kualitas Pelayanan Terhadap Kepuasan Konsumen Pada Hotel Manado Grace Inn." Berdasarkan hasil pengujian menunjukan hasil perhitungan secara parsial yaitu signifikansi $0.002<0.05$, yang berarti bahwa harga (X1) berpengaruh signifikan terhadap kepuasan komsumen (Y).

$\mathrm{H}_{5}$ : Harga berpengaruh terhadap kepuasan pengguna aplikasi Ruang Guru.

\section{MODEL PENELITIAN} digunakan.

Gambar 1 merupakan Model Penelitian beserta indikator penelitian yang

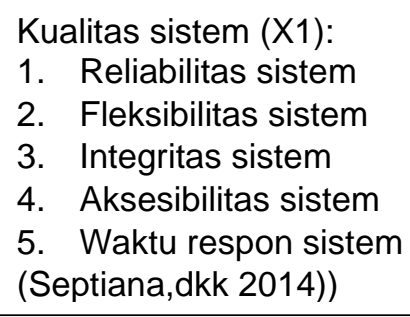

3. Integritas sistem

4. Aksesibilitas sistem

5. Waktu respon sistem (Septiana,dkk 2014))

Persepsi Kemudahan (X2):

1. Mudah dipelajari

2. Dapat dikontrol

3. Jelas dan dapat dipahami

4. Fleksibilitas

5. Mudah untuk menjadi terampil

6. Mudah digunakan

(ME Widiana, H Supit, S Hartini 2012)

Iklan (X3) :

1. Tujuan

2. Pesan yang disampaikan

3. Media yang digunakan (Kotler 2013:143)

Promosi (X4):

1. Periklanan

2. Promosi penjualan

3. Hubungan masyarakat dan publisitas

4. Penjualan secara pribadi

5. Pemasaran langsung

(S Nangoy, SL Mandey, L Kawet 2017)

Harga (X5):

1. Perbandingan harga dengan produk lain

2. Kesesuaian harga dengan kualitas produk

3. Keterjangkauan harga (S Nangoy, SL Mandey, L Kawet 2017) 
Rumusan hipotesis yang digunakan dalam penelitian ini adalah:

$\mathrm{H1}$ : kualitas sistem berpengaruh terhadap kepuasan pengguna.

$\mathrm{H} 2$ : persepsi kemudahan berpengaruh terhadap kepuasan pengguna.

H3: iklan berpengaruh terhadap kepuasan pengguna.

$\mathrm{H} 4$ : promosi berpengaruh terhadap kepuasan pengguna.

H5: harga berpengaruh terhadap kepuasan pengguna.

H6: kualitas sistem, persepsi kemudahan, iklan, promosi dan harga secara bersama-sama berpengaruh terhadap kepuasan pengguna.

\section{OPERASIONAL VARIABEL}

Operasionalisasi variabel adalah proses penentuan ukuran suatu variabel agar dapat memperoleh nilai yang tepat bagi variabel-variabel yang diteliti.

Tabel 1

Indikator Penelitian

\begin{tabular}{|c|c|c|c|c|}
\hline No & Variabel & Indikator & Kode & Keterangan \\
\hline \multirow{4}{*}{1} & \multirow{4}{*}{$\begin{array}{l}\text { Kualitas } \\
\text { sistem }\end{array}$} & Reliabilitas sistem & KS1 & $\begin{array}{l}\text { Aplikasi ruangguru memiliki } \\
\text { sistem yang andal untuk } \\
\text { dioperasikan. }\end{array}$ \\
\hline & & Fleksibilitas sistem & $\mathrm{KS} 2$ & $\begin{array}{l}\text { Aplikasi ruangguru memiliki } \\
\text { sistem yang dapat menyesuaikan } \\
\text { dengan berbagai kebutuhan dan } \\
\text { kondisi. }\end{array}$ \\
\hline & & Aksesibilitas sistem & $\mathrm{KS} 3$ & $\begin{array}{l}\text { Aplikasi ruangguru dapat } \\
\text { mengakses informasi dengan } \\
\text { mudah. }\end{array}$ \\
\hline & & Waktu respon sistem & KS4 & $\begin{array}{l}\text { Waktu respon sistem aplikasi } \\
\text { ruangguru yang cepat atau tepat } \\
\text { waktu terhadap permintaan } \\
\text { informasi. }\end{array}$ \\
\hline \multirow{5}{*}{2} & \multirow{5}{*}{$\begin{array}{l}\text { Persepsi } \\
\text { Kemudahan }\end{array}$} & $\begin{array}{l}\text { Mudah } \\
\text { dipelajari/dipahami }\end{array}$ & PK1 & $\begin{array}{l}\text { Pengguna dapat dengan jelas } \\
\text { memahami bagaimana } \\
\text { mempelajari aplikasi ruangguru. }\end{array}$ \\
\hline & & Dapat dikontrol & PK2 & $\begin{array}{l}\text { Fasilitas dan fitur yang } \\
\text { disediakan aplikasi ruangguru } \\
\text { berfungsi dengan baik. }\end{array}$ \\
\hline & & $\begin{array}{l}\text { Jelas dan dapat } \\
\text { dipahami }\end{array}$ & PK3 & $\begin{array}{l}\text { Fasilitas atau fitur aplikasi } \\
\text { ruangguru sesuai dengan } \\
\text { kegunaanya. }\end{array}$ \\
\hline & & Fleksibilitas & PK4 & $\begin{array}{l}\text { Aplikasi ruangguru dapat } \\
\text { digunakan kapan saja tanpa } \\
\text { terbatas ruang dan waktu. }\end{array}$ \\
\hline & & $\begin{array}{l}\text { Mudah untuk menjadi } \\
\text { terampil/mahir }\end{array}$ & PK5 & $\begin{array}{l}\text { Dalam penggunaan selanjutnya } \\
\text { pengguna dapat mengakses } \\
\text { aplikasi ruangguru dengan } \\
\text { mudah sesuai keinginannya } \\
\text { setelah satu kali } \\
\text { menggunakannya. }\end{array}$ \\
\hline
\end{tabular}




\begin{tabular}{|c|c|c|c|c|}
\hline No & Variabel & Indikator & Kode & Keterangan \\
\hline & & $\begin{array}{l}\text { Mudah } \\
\text { dioperasikan/digunakan }\end{array}$ & PK6 & $\begin{array}{l}\text { Aplikasi ruangguru dapat } \\
\text { digunakan secara mudah dan } \\
\text { dinamis. }\end{array}$ \\
\hline \multirow{3}{*}{3} & \multirow{3}{*}{ Iklan } & Tujuan & IK1 & $\begin{array}{l}\text { Iklan aplikasi ruangguru mudah } \\
\text { untuk diingat pengguna. }\end{array}$ \\
\hline & & Pesan yang disampaikan & IK2 & $\begin{array}{l}\text { Iklan aplikasi ruangguru } \\
\text { menarik saya untuk } \\
\text { menggunakan aplikasinya. }\end{array}$ \\
\hline & & Media yang digunakan & IK3 & $\begin{array}{l}\text { Iklan aplikasi ruangguru dapat } \\
\text { dilihat diberbagai media. }\end{array}$ \\
\hline \multirow{4}{*}{4} & \multirow{4}{*}{ Promosi } & Periklanan & PS1 & $\begin{array}{l}\text { Aplikasi ruangguru dapat dilihat } \\
\text { melalui iklan. }\end{array}$ \\
\hline & & Promosi Penjualan & PS2 & $\begin{array}{l}\text { Aplikasi ruangguru memberikan } \\
\text { diskon untuk pengguna pertama. }\end{array}$ \\
\hline & & $\begin{array}{l}\text { Hubungan masyarakat } \\
\text { dan publisitas }\end{array}$ & PS3 & $\begin{array}{l}\text { Promosi yang dilakukan aplikasi } \\
\text { ruangguru memiliki hubungan } \\
\text { langsung dengan masyarakat. }\end{array}$ \\
\hline & & Pemasaran Langsung & PS4 & $\begin{array}{l}\text { Promosi yang dilakukan aplikasi } \\
\text { ruangguru bertujuan untuk } \\
\text { memperoleh tanggapan segera } \\
\text { atupun membangun hubungan. }\end{array}$ \\
\hline \multirow{3}{*}{5} & \multirow{3}{*}{ Harga } & $\begin{array}{l}\text { Perbandingan dengan } \\
\text { produk lain }\end{array}$ & HG1 & $\begin{array}{l}\text { Aplikasi ruangguru memberikan } \\
\text { harga lebih murah dari pesaing. }\end{array}$ \\
\hline & & $\begin{array}{l}\text { Kesesuaian harga } \\
\text { dengan kualitas produk }\end{array}$ & HG2 & $\begin{array}{l}\text { Harga yang ditawarkan aplikasi } \\
\text { ruangguru sudah sesuai dengan } \\
\text { kualitas yang didapatkan. }\end{array}$ \\
\hline & & Keterjangkauan harga & HG3 & $\begin{array}{l}\text { Harga yang ditetapkan } \\
\text { terjangkau oleh pengguna } \\
\text { aplikasi ruangguru. }\end{array}$ \\
\hline \multirow{4}{*}{6} & \multirow{4}{*}{$\begin{array}{l}\text { Kepuasan } \\
\text { Pengguna }\end{array}$} & Isi & KP1 & $\begin{array}{l}\text { Informasi yang disediakan } \\
\text { aplikasi ruangguru sesuai } \\
\text { dengan harapan pengguna. }\end{array}$ \\
\hline & & Akurasi & KP2 & $\begin{array}{l}\text { Kesesuaian fitur dan layanan } \\
\text { aplikasi ruangguru. }\end{array}$ \\
\hline & & Ketepatan Waktu & KP3 & $\begin{array}{l}\text { Pengguna tidak menunggu } \\
\text { terlalu lama ketika } \\
\text { menggunakan aplikasi } \\
\text { ruangguru. }\end{array}$ \\
\hline & & Mudah digunakan & KP4 & $\begin{array}{l}\text { Pengguna dapat dengan mudah } \\
\text { menggunakan aplikasi } \\
\text { ruangguru. }\end{array}$ \\
\hline
\end{tabular}




\section{HASIL PENELITIAN DAN PEMBAHASAN}

Pada bagian ini akan menjelaskan hasil pengujian data dan asumsi model.

\subsection{Pengujian Data}

\section{Uji Multikolinearitas}

Uji multikolinearitas untuk untuk mengukur apakah terdapat korelasi tinggi antara kualitas sistem, persepsi kemudahan, iklan, promosi, dan harga. Pada uji multikolinearitas ini menggunakan nilai VIF (Variance Inflation Factor) sebagai tolak ukur untuk mengambil keputusan. Batas nilai VIF yang ditetapkan pada penelitian ini sebesar 10, dimana nilai VIF tidak boleh melebihi angka 10.

Tabel 2

Uji Multikolinearitas

\begin{tabular}{|l|c|c|}
\hline \multicolumn{3}{|c|}{ Coefficients $^{\text {a }}$} \\
\hline \multirow{2}{*}{ Model } & \multicolumn{2}{|c|}{$\begin{array}{c}\text { Collinearity } \\
\text { Statistics }\end{array}$} \\
\cline { 2 - 3 } & Tolerance & VIF \\
\hline (Constant) &. & \\
KS_Total & .459 & 2.180 \\
PK_Total & .367 & 2.725 \\
IK_Total & .472 & 2.119 \\
PM_Total & .418 & 2.393 \\
HG_Total & .576 & 1.737 \\
\hline
\end{tabular}

a. Dependent Variable: TOT_KPM

Berdasarkan tabel 2 dapat dilihat bahwa nilai VIF untuk variabel kualitas sistem sebesar 2.180, persepsi kemudahan sebesar 2.725, iklan sebesar 2.119, promosi sebesar 2.393, dan harga sebesar 1.737. Nilai VIF kelima variabel bebas dalam penelitian ini kurang dari 10, maka perumusan $\mathrm{H} 1$ diterima, yang berarti tidak ada multikolinearitas antara kualitas sistem, persepsi kemudahan, iklan, promosi, dan harga terhadap kepuasan pengguna.

\section{Uji Heteroskedastisitas}

Uji heteroskedastisitas bertujuan untuk mengetahui apakah dalam model regresi terjadi ketidaksamaan varians dari residual satu pengamatan ke pengamat yang lain. Berdasarkan gambar 2 grafik scatterplot dapat dilihat bahwa titik-titik menyebar secara tidak teratur diatas dan dibawah angka nol pada sumbu Y. Oleh karena itu, dapat disimpulkan bahwa dalam penelitian ini tidak terjadi heteroskedastisitas (bersifat homoskedastisitas). 


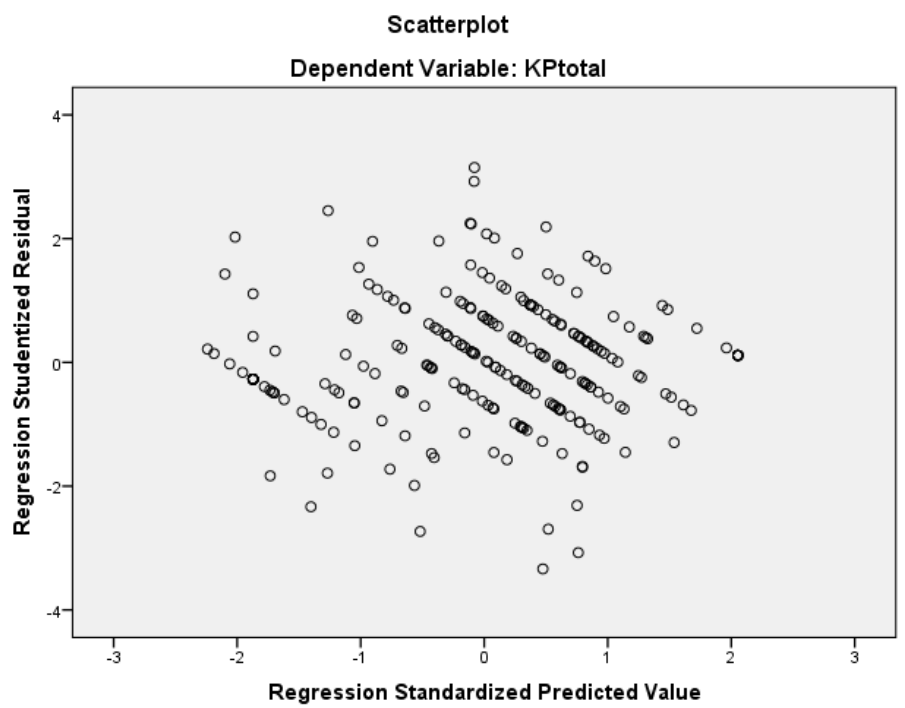

Gambar 2

Hasil Uji Heteroskedastisitas

\section{Uji Normalitas}

Uji normalitas dilakukan untuk mengetahui apakah penelitian berdistribusi normal atau tidak, dengan melihat hasil output berupa histogram dan normal probability plots.

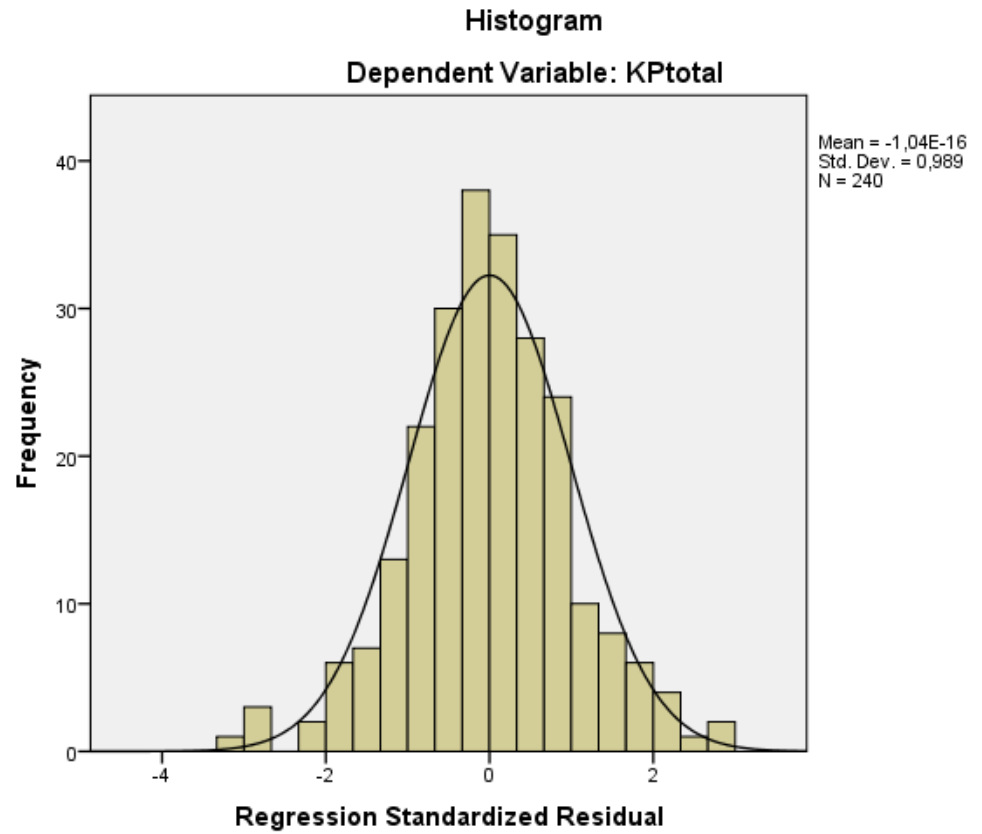

Gambar 3

Histogram 


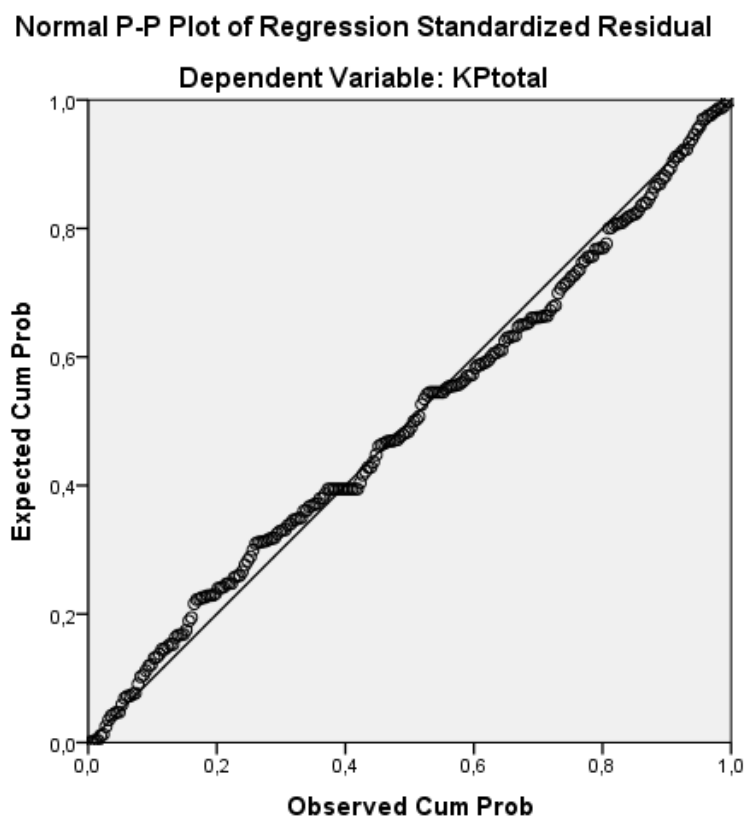

Gambar 4

Normal Probability Plots

Berdasarkan gambar 3 yang berupa histogram, kurva yang dihasilkan berbentuk lonceng dan cenderung simetris. Sedangkan pada gambar 4, titik-titik pada grafik normal probability plots menyebar mengikuti arah garis diagonal pada grafik. Sehingga dapat disimpulkan bahwa model regresi pada penelitian ini terdistribusi normal.

\section{Uji Validitas}

Uji validitas digunakan dalam penelitian untuk mengetahui apakah setiap butir pertanyaan yang dibuat valid atau tidak valid. Dalam penelitian ini, suatu butir pertanyaan dianggap valid jika nilai indeks yang dihasilkan dari pengolahan SPSS lebih besar dari 0,4.

Tabel 3

Uji Validitas

\begin{tabular}{|c|c|c|c|c|}
\hline Variabel & Indikator & Sig. & $\begin{array}{c}\text { Nilai } \\
\text { Indeks }\end{array}$ & Status \\
\hline \multirow{4}{*}{$\begin{array}{c}\text { Kualitas } \\
\text { Sistem }\end{array}$} & Reliabilitas sistem & 0.000 & 0.771 & Valid \\
\cline { 2 - 5 } & Fleksibilitas sistem & 0.000 & 0.753 & Valid \\
\cline { 2 - 5 } & Aksesibilitas sistem & 0.000 & 0.764 & Valid \\
\cline { 2 - 5 } & Waktu Respon Sistem & 0.000 & 0.761 & Valid \\
\hline \multirow{4}{*}{$\begin{array}{c}\text { Persepsi } \\
\text { Kemudahan }\end{array}$} & $\begin{array}{c}\text { Mudah } \\
\text { dipelajari/dipahami }\end{array}$ & 0.000 & 0.708 & Valid \\
\cline { 2 - 5 } & Dapat dikontrol & 0.000 & 0.710 & Valid \\
\cline { 2 - 5 } & $\begin{array}{c}\text { Jelas dan dapat } \\
\text { dipahami }\end{array}$ & 0.000 & 0.682 & Valid \\
\cline { 2 - 5 } & Fleksibilitas & 0.000 & 0.725 & Valid \\
\hline
\end{tabular}




\begin{tabular}{|c|c|c|c|c|}
\hline Variabel & Indikator & Sig. & $\begin{array}{c}\text { Nilai } \\
\text { Indeks }\end{array}$ & Status \\
\hline \multirow{4}{*}{ Iklan } & $\begin{array}{c}\text { Mudah untuk menjadi } \\
\text { terampil/mahir }\end{array}$ & 0.000 & 0.749 & Valid \\
\cline { 2 - 5 } & Mudah digunakan & 0.000 & 0.731 & Valid \\
\cline { 2 - 5 } & Tujuan & 0.000 & 0.814 & Valid \\
\cline { 2 - 5 } & $\begin{array}{c}\text { Pesan yang } \\
\text { disampaikan }\end{array}$ & 0.000 & 0.811 & Valid \\
\cline { 2 - 5 } & Media yang digunakan & 0.000 & 0.730 & Valid \\
\cline { 2 - 5 } & Promosi & 0.000 & 0.674 & Valid \\
\cline { 2 - 5 } & $\begin{array}{c}\text { Pubungan masyarakat } \\
\text { dan publisitas }\end{array}$ & 0.000 & 0.754 & Valid \\
\cline { 2 - 5 } & Pemasaran langsung & 0.000 & 0.746 & Valid \\
\hline \multirow{5}{*}{ Harga } & $\begin{array}{c}\text { Perbandingan dengan } \\
\text { produk lain }\end{array}$ & 0.000 & 0.851 & Valid \\
\cline { 2 - 5 } & $\begin{array}{c}\text { Kesesuaian harga } \\
\text { dengan kualitas } \\
\text { produk }\end{array}$ & 0.000 & 0.861 & Valid \\
\cline { 2 - 5 } & keterjangkauan harga & 0.000 & 0.868 & Valid \\
\hline
\end{tabular}

Seluruh butir pertanyaan variabel kualitas sistem, persepsi kemudahan, iklan, promosi, dan harga memiliki nilai indeks yang lebih besar dari 0.40, maka dapat disimpulkan bahwa butir pertanyaan dari variabel kualitas sistem dinyatakan valid.

\section{Uji Reliabilitas}

Uji reliabilitas untuk mengukur kestabilan atau konsistensi jawaban terhadap pertanyaan kuesioner dari waktu ke waktu. Pada uji reliabilitas menggunakan nilai Cronbach's Alpha dimana batasan nilai Cronbach's Alpha harus lebih besar dari 0,6 sebagai tolak ukur reliabilitas indikator sebuah variabel.

Tabel 4

Uji Reliabilitas

\begin{tabular}{|c|c|c|}
\hline Variabel & Cronbach's Alpha & Status \\
\hline Kualitas Sistem & 0.758 & Reliabel \\
\hline Persepsi Kemudahan & 0.812 & Reliabel \\
\hline Iklan & 0.686 & Reliabel \\
\hline Promosi & 0.698 & Reliabel \\
\hline Harga & 0.823 & Reliabel \\
\hline Kepuasan Pengguna & 0.774 & Reliabel \\
\hline
\end{tabular}

Analisis hasil uji reliabilitas keseluruhan masing-masing variabel berdasarkan Tabel 4, menunjukkan semua nilai Cronbach's Alpha untuk keseleruhan instrumen variabel kualitas sistem, persepsi kemudahan, iklan, promosi, harga dan kepuasan pengguna lebih besar dari 0,5 , artinya seluruh indikator dinyatakan reliabel. 


\section{Uji Korelasi}

Uji korelasi yang digunakan dalam penelitian ini adalah uji korelasi Pearson. Pengujian ini dilakukan untuk mengetahui ada atau tidaknya hubungan antar variabel bebas yaitu kualitas sistem, persepsi kemudahan, iklan, promosi, dan harga terhadap variabel terikatnya yaitu kepuasan pengguna. Perhitungan korelasi menggunakan taraf signifikansi pada probabilitas $5 \%(0,05)$.

Hasil pengujian korelasi antara variabel kualitas sistem dengan variabel kepuasan pengguna, menunjukan nilai pearson correlation sebesar 0,653 (positif, hubungan kuat) yang artinya jika nilai variabel kualitas sistem meningkat, maka nilai variabel kepuasan pengguna juga akan meningkat. Serta diperoleh nilai signifikan (2-tailed) sebesar 0,000 $<0,05$, maka disimpulkan bahwa adanya hubungan antara kualitas sistem dengan kepuasan pengguna.

Hasil pengujian korelasi antara variabel persepsi kemudahan dengan variabel kepuasan pengguna, menunjukan nilai pearson correlation sebesar 0,746 (positif, hubungan kuat) yang artinya jika nilai variabel persepsi kemudahan meningkat, maka nilai variabel kepuasan pengguna juga akan meningkat. Serta diperoleh nilai signifikan (2-tailed) sebesar $0,000<0,05$, maka disimpulkan bahwa adanya hubungan antara persepsi kemudahan dengan kepuasan pengguna.

Hasil pengujian korelasi antara variabel iklan dengan variabel kepuasan pengguna, menunjukan nilai pearson correlation sebesar 0,571 (positif, hubungan sedang) yang artinya jika nilai variabel iklan meningkat, maka nilai variabel kepuasan pengguna juga akan meningkat. Serta diperoleh nilai signifikan (2tailed) sebesar $0,000<0,05$, maka disimpulkan bahwa adanya hubungan antara iklan dengan kepuasan pengguna.

Hasil pengujian korelasi antara variabel promosi dengan variabel kepuasan pengguna, menunjukan nilai pearson correlation sebesar 0,638 (positif, hubungan kuat) yang artinya jika nilai variabel promosi meningkat, maka nilai variabel kepuasan pengguna juga akan meningkat. Serta diperoleh nilai signifikan (2-tailed) sebesar 0,000 $<0,05$, maka disimpulkan bahwa adanya hubungan antara promosi dengan kepuasan pengguna.

Hasil pengujian korelasi antara variabel harga dengan variabel kepuasan pengguna, menunjukan nilai pearson correlation sebesar 0,601 (positif, hubungan kuat) yang artinya jika nilai variabel harga meningkat, maka nilai variabel kepuasan pengguna juga akan meningkat. Serta diperoleh nilai signifikan (2tailed) sebesar $0,000<0,05$, maka disimpulkan bahwa ada hubungan antara harga dengan kepuasan pengguna.

\subsection{Koefisien Regresi dan Determinasi}

Dalam penelitian ini model yang digunakan adalah model regresi linear berganda. Berikut adalah hasil regresi liniear berganda mengenai pengaruh kualitas sistem, persepsi kemudahan, iklan, promosi, dan harga terhadap kepuasan pengguna. 
Tabel 5

Uji Regresi Linear Berganda

\begin{tabular}{|c|c|c|c|c|c|c|}
\hline \multicolumn{7}{|c|}{ Coefficients $^{\mathbf{a}}$} \\
\hline & \multirow[t]{2}{*}{ Model } & \multicolumn{2}{|c|}{$\begin{array}{l}\text { Unstandardized } \\
\text { Coefficients }\end{array}$} & \multirow{2}{*}{$\begin{array}{c}\text { Standardized } \\
\text { Coefficients } \\
\text { Beta } \\
\end{array}$} & \multirow[t]{2}{*}{$\mathrm{t}$} & \multirow[t]{2}{*}{ Sig. } \\
\hline & & $\mathrm{B}$ & Std. Error & & & \\
\hline \multirow[t]{6}{*}{1} & (Constant) & 1,228 &, 758 & & $\begin{array}{r}1,62 \\
1\end{array}$ & , 106 \\
\hline & Kstotal &, 175 &, 058 &, 176 & $\begin{array}{r}3,00 \\
7\end{array}$ & ,003 \\
\hline & Pktotal & ,299 & ,048 & ,410 & $\begin{array}{r}6,26 \\
4 \\
\end{array}$ & ,000 \\
\hline & Iktotal & ,022 & 071 & 018, & ,317 & ,751 \\
\hline & Pmtotal &, 140 & ,063 & , 136 & $\begin{array}{r}2,21 \\
9\end{array}$ & ,027 \\
\hline & Hgtotal & ,200 & ,056 & , 187 & $\begin{array}{r}3,58 \\
1\end{array}$ & ,000 \\
\hline
\end{tabular}

Dengan demikian persamaan umum regresi linear berganda nya adalah :

$$
Y=1,228+0,175 X_{1}+0,299 X_{2}+0,022 X_{3}+0,140 X_{4}+0,200 X_{5}
$$

Keterangan:

$\mathrm{Y}=$ Kepuasan pengguna

$\mathrm{X}_{1}=$ Kualitas sistem

$\mathrm{X}_{2}=$ Persepsi kemudahan

$\mathrm{X}_{3}=$ Iklan

$\mathrm{X}_{4}=$ Promosi

$\mathrm{X}_{5}=$ Harga

Analisis koefisien regresi :

a. Nilai konstanta sebesar 1.228, hal ini berarti bahwa jika variabel bebas kualitas sistem, persepsi kemudahan, iklan, promosi, dan harga bernilai nol maka kepuasan pengguna berkurang sebesar 1.228.

b. Nilai koefisien kualitas sistem sebesar 0,175 yang berarti bahwa jika kualitas sistem meningkat sebesar satu satuan maka kepuasan pengguna akan meningkat sebesar 0,175 satuan dengan syarat persepsi kemudahan, iklan, promosi, dan harga bernilai tetap.

c. Nilai koefisien persepsi kemudahan sebesar 0,299 yang berarti bahwa jika persepsi kemudahan meningkat sebesar satu satuan maka kepuasan pengguna akan meningkat sebesar 0,299 satuan dengan syarat kualitas sistem, iklan, promosi, dan harga bernilai tetap.

d. Nilai koefisien iklan sebesar 0,022 yang berarti jika iklan meningkat sebesar satu satuan maka kepuasan pengguna akan meningkat sebesar 0,022 satuan dengan syarat kualitas sistem, persepsi kemudahan, promosi, dan harga bernilai tetap.

e. Nilai koefisien promosi sebesar 0,140 yang berarti jika promosi meningkat sebesar satu satuan maka kepuasan pengguna akan meningkat sebesar 0,140 
satuan dengan syarat kualitas sistem, persepsi kemudahan, iklan, dan harga bernilai tetap.

f. Nilai koefisien harga sebesar 0,200 yang berarti jika harga meningkat sebesar satu satuan maka kepuasan pengguna akan meningkat sebesar 0,200 satuan dengan syarat kualitas sistem, persepsi kemudahan, iklan, dan promosi bernilai tetap.

Tabel 6

Uji Koefesien Determinasi

\begin{tabular}{|c|c|c|c|c|}
\hline \multicolumn{5}{|c|}{ Model Summary } \\
\hline Model & $\mathrm{R}$ & $\begin{array}{c}\mathrm{R} \\
\text { Square }\end{array}$ & $\begin{array}{c}\text { Adjusted R } \\
\text { Square }\end{array}$ & $\begin{array}{c}\text { Std. Error of the } \\
\text { Estimate }\end{array}$ \\
\hline 1 &, $795^{\mathrm{a}}$ &, 631 &, 623 & 1,465 \\
\hline \multicolumn{2}{|c|}{ a. Predictors: (Constant), HGtotal, KStotal, IKtotal, PMtotal, PKtotal } \\
\hline
\end{tabular}

Nilai koefisien determinasi dapat dilihat pada tabel pada kolom adjusted $\mathrm{R}$ square sebesar 0,623. Nilai tersebut menunjukkan bahwa kualitas sistem, persepsi kemudahan, iklan, promosi, dan harga terhadap kepuasan pengguna sebesar $62,3 \%$ dan $37,7 \%$ dipengaruhi oleh faktor-faktor lain yang tidak dibahas dalam penelitian ini.

\section{KESIMPULAN}

Dari penelitian ini dapat ditarik kesimpulan sebagai berikut :

a. Ada pengaruh yang signifikan secara parsial (individu) antara kualitas sistem, persepsi kemudahan, promosi dan harga secara signifikan terhadap kepuasan pengguna aplikasi Ruangguru.

b. Tidak ada pengaruh yang signifikan secara parsial (individu) antara iklan terhadap kepuasan pengguna aplikasi Ruangguru.

c. Ada pengaruh secara simultan (bersama-sama) antara variabel kualitas sistem, persepsi kemudahan, iklan, promosi, dan harga terhadap kepuasan pengguna aplikasi Ruangguru.

d. Nilai koefisien determinasi sebesar 0,623 yang menunjukkan bahwa kualitas sistem, persepsi kemudahan, iklan, promosi, dan harga terhadap kepuasan pengguna sebesar $62,3 \%$ dan $37,7 \%$ dipengaruhi oleh faktor-faktor lain yang tidak dibahas dalam penelitian ini.

\section{DAFTAR PUSTAKA}

Amstrong, Kottler. 1997. “Prinsip-Prinsip Pemasaran”, Erlangga, Jakarta.

Aprianto, Ronal. 2016. Pengaruh Promosi Dan Pelayanan Terhadap Kepuasan Pelanggan Pada Toko BNJ Elektronik. Lubuklinggau: Sekolah Tinggi Ilmu Musi Rawas.

Chen, C. F., \& Chen, F. S. 2010. Experience Quality, Perceived Value, Satisfaction and Behavioral Intentions for Heritage Tourists. Tourism Management, 31, 29-35.

Davis,F.D. 1989. "Perceived Usefulness, Perceived Ease of Use, and User Acceptance of Information Technology”. MIS Quarterly.Vol. 13 No. 5: pp319-339. 
Dewi, Kasuma, Nila, dkk. 2012. Pengaruh Iklan, Citra Merek, dan Kepuasan Konsumen Terhadap Loyalitas Konsumen Dalam Menggunakan Vaseline Hand and Body Lotion Di Kota Padang. Padang: Universitas Tamansiswa.

Fendini, Dian Septiayu, dkk. 2013. Pengaruh Kualitas Sistem dan Kualitas Informasi terhadap Kepuasan Pengguna. Malang : Universitas Brawijaya.

Gulla, Rendy, Sem George Oroh, dan Ferdy Roring. 2015. Analisis Harga, Promosi, Dan Kualitas Pelayanan Terhadap Kepuasan Konsumen Pada Hotel Manado Grace Inn. Manado: Universitas Sam Ratulangi Manado.

Hutahaean, Jeperson. 2014. Konsep Sistem Informasi. Yogyakarta: Deepublish.

Jogiyanto, 2007. Sistem Informasi Keprilakuan. Yogyakarta. Andi.

Kasali, Rhenald. 2000. Manajemen Public Relations. Jakarta : PT. Temprint.

Kotler, Philip., Keller, Kevin L. 2013. Manajemen Pemasaran, Jilid Kedua, Jakarta: Erlangga.

Laudon, Kenneth C., and Jane P. Laudon, 2014. Management Information Systems: Managing The Digital Firm, 13 th Ed, Person Education Limited, New York University - United States of America.

Nelson, R. R., Todd, P. A., and Wixom, B. H. 2005. Antecedents of Information and System Quality: An Empirical Examination Within The Context of Data Warehousing.

Noviarni, 2014, Perencanaan Pembelajaran Matematika dan Aplikasinya, Pekanbaru: Benteng Media.

Rukmiyati, N., dan I Ketut Budiartha. 2016. Pengaruh Kualitas Sistem Informasi, Kualitas Informasi, dan Perceived Usefulness Pada Kepuasan Pengguna Akhir Software Akuntansi. Bali: Universitas Udayana.

Saladin, Djaslim. 2007. Manajemen Pemasaran. Bandung. PT Linda Karya.

Somers, T. M., Nelson, K. and Karimi, J. 2003. Confirmatory factor analysis of the end-user computing satisfaction instrument: Replication within an ERP domain. Decision Sciences. Vol 34.

Sukirno, Sadono. 2014. Ekonomi Pembangunan: Proses, masalah, dan dasar Kebijakan (edisi ke kedua). Jakarta : Kencana Prenadamedia Group.

Swastha, Basu. 2007, Manajemen Pemasaran Modern, Liberty Offset, Yogyakarta.

Tjiptono, Fandy, 2008, Strategi Pemasaran, Edisi 3, ANDI: Yogyakarta. 